\title{
視運動性眼振と関連するネコ網膜神経節細胞の分布について
}

\author{
岡田 智幸・加藤 功・渡辺 昭司 \\ 佐藤 成樹・竹山 勇
}

\section{Retinal Ganglion Cells Projecting to the Nucleus of the Optic Tract in the Cat}

Tomoyuki Okada, Isao Kato, Shoji Watanabe

Shigeki Sato, Isamu Takeyama

Department of Otorhinolaryngology, St. Marianna University School of Medicine

The nucleus of the optic tract (NOT) in the pretectum in both afoveate and foveate mammals has been considered to be the interface between the retina and premotor nuclei in the pathway conveying signals responsible for horizontal optokinetic nystagmus (OKN). Howevr, the parts of the retina and the kinds of retinal ganglion cells project which their fibers into the NOT are still not completely known.

To clarify this pathway, we injected horseradish peroxidase conjugated with wheatgerm agglutinin into the NOT of the cats. In both retinae, labeled retinal ganglion cells were observed only above the horizontal meridian through the optic disc, and they were situated mainly in the temporal retina lateral to a vertical line through the disc.

In both retinae, the highest concentration of labeled cells was the area centralis and the region adjacent to it. Most of the labeled cells were small cells, i.e., $\mathrm{W}$ cells.

However, X-like cells and Y-like cells were also definitely labeled, suggesting that these cells pariticipate in OKN.

Key words: NOT, Retinal ganglion cells, OKN, HRP, Cat

\section{緒言}

水平性視運動性眼振 (OKN) は, 比較的原始的 な視覚機能で，移動する対象物に対して生ずる眼 位の移動の反復であり，中心简の有無にかかわら ず，動物にも観察される生理的眼振である”。し かし，視覚入力レベルすなわち網膜において，網

聖マリアンナ医科大学耳鼻咽喉科学教室

（主任：竹山 勇教授）
膜上のよ゙のような部位の，どのような種類の網膜 神経節細胞が OKN の役割を担っているのかは形 態的に論議もみられ，未解明の点も多い。 地面を這う小動物の代表とされるラットでは， 逆行性軸索移動物質である Horseradish peroxidase conjugated with wheatgerm agglutinin (WGA-HRP) を視索核 (NOT) に注入し，網膜神 経節細胞を組織化学的に標識させる実験で1 3), OKN の視覚情報は対側網膜亚びに同側の腹側網 
膜とが役割分担を行い，またラットの眼位から みて鼻前上部の視野の binocular overlapがあり， ラットが自然界を生きていく上で,これら標識さ れた網膜神経節細胞が合目的に機能している可能 性が示唆された。一方，地面を這う小動物を獲物 とするネコにおいては Ballas ら"), Sawai ら5)の 報告をみるが OKN に関する網膜神経節細胞の種 類については一致をみていない。

したがって今回は実験上, 高等動物とされるネ コを用いて, OKN の視覚情報の入力レベルと $\mathrm{O}$ $\mathrm{KN}$ の第一中継核である視索核 (NOT) ${ }^{6)}$ 10) との 結びつきを調べる目的で, WGA-HRPをNOTに 注入し, 網膜神経節細胞を組織化学的に標識させ, 注入部位之同側並びに対側の網膜について検討し, 若干の知見を得たので報告する。

\section{実験方法}

実験にはメスの成熟ネコ（1500-2000g）を用い, ペントバルビタール $(20 \mathrm{mg} / \mathrm{kg})$ を腹腔内投与し て麻酔を施した。

ネコに扔いて形態学的に NOT の部位は確かめ られているため, ear bar から左前方約 $5 \mathrm{~mm}$, 正中線から左方約 $2 \mathrm{~mm}$ の位置に歯科用バーで直 径約 $3 \mathrm{~mm}$ の穴をあけ, 顕微鏡下に大脳を吸引除 去し，左 NOT 周囲を明視下においた。

WGA-HRP の注入には加圧法を用い, 微量注 入するため, $1 \mu 1$ のマ.イクロシリンジの先に微少 ガラス管をwax paraffin で固定した。10\%WG A-HRP をマイクロシリンジにて 10-20 分で 0.02$0.04 \mu 1$ を全て左侧に注入した。WGA-HRP 注入 後, 48 時間生存期間をおいて, 生理食塩水 $300 \mathrm{ml}$ による灌流，次いで $0.1 \mathrm{M}$ リン酸緩衝液 $(\mathrm{pH} 7.4)$ で調整された $4 \%$ パラホルムアルデヒドと 1.25 $\%$ グルタールアルデヒド水溶液 $300 \mathrm{ml}$ により灌 流，固定した。

灌流, 固定後直ちに, 脳と左右眼球を摘出し, $0.1 \mathrm{M}$ リン酸緩衝液（pH 7.4）で調整された $20 \%$ ショ糖に摘出した脳を入れ, 冷蔵莗に保存し, 組 織が容器の底に沈んだのを確かめてから（一昼夜 後), 脳を凍結させ 40-60 $\mu \mathrm{m}$ の連続切片を作製し た。

一方, 左右眼球摘出時には，まず，外眼角と内 眼角とを結ぶ直線に垂直な面で, メスにて眼球上 部強膜に割面をいれ，それを目印として眼科用八 サミを用いて眼球を摘出した。摘出した眼球の球
結膜と強膜との移行部の強膜側をメスを入れ, 眼 科用八サミにて球結膜側と強膜側とを円形に切離 $し$, 強膜側の半球部分に残った内側の網膜をシェ 一氏剥離子を用いて剥離して眼杯 (eye cup) とし た。さらに一連の作業として, 眼杯は Olucha ら の TMB 法 ${ }^{11)}$ に基づいて反応させた。また，網膜 上部の目印を確かめながら必要に応じて眼杯にメ スを入れ, 眼杯伸展標本とし, エタノール系列で 脱水後, 標本封入剂で封入した。

網膜神経節細胞の分布及び細胞体の大きさにつ いては typewriter により作製したアルファベッ 卜列並びに数列の表の写真を撮り，そのネガフィ ルムを眼杯伸展標本作製プレパラートに載せ, 網 膜神経節細胞の分布が最も均一している各部位 (腹側部, 鼻側部, 側頭部, 中心部, 背側部) の写 真を撮った。プリントはアルファベットの文字が 250 倍になるように作製した。尚, 眼杯伸展標本 は $-20^{\circ} \mathrm{C}$ で保存した。

プリントに写った網膜神経節細胞を牛方商会製 X-plan 360iを用いて，明確にプリントされてい る網膜神経節細胞の細胞体をトレースし, 直ちに コンピュータ処理して面積を算定し, 各々の細胞 体の大きさ (soma area) とした。同時に各部位 の単位面積 $\left(1 \mathrm{~mm}^{2}\right)$ あたりの個数 (密度) 算定 し,コンピュータ娃理した。

WGA-HRP の注入部位の組織化学的検出につ いては，凍結連続切片をスライドガラスに載せた まま, Mesulam の方法 (TMB 法 : tetramethyl benzidine 法 ${ }^{123}$ 13) を用いた。反応終了後, 自然乾 燥させ，1\% neutral red 液にて対比染色を行い， エタノール系列で脱水後, 標本封入剂で封入し, 注入部位及び HRP 標準細胞の分布を調べた。

実験に供し，WGA-HRP を注入した成熟ネコは 8匹で，全て左 NOT に注入した。なお，視蓋前 域の核の名称は, Kanaseki \& Sprague $(1974)^{14}$ を参考にした。また実験方法の詳細等は岡田" 報告に基づいた。

\section{結果}

NOT 注入例 8 匹中 2 匹は注入部位が NOT を 中心に認められ，拡散が比較的小さく，残りの6 匹についてはWGA-HRP の注入部位が NOT を 中心に比較的大きく，周囲への拡散が大であった。 TMB 法により標識された HRP の注入部位およ びその拡散が最も限局していたネコNo.48 (C48) 


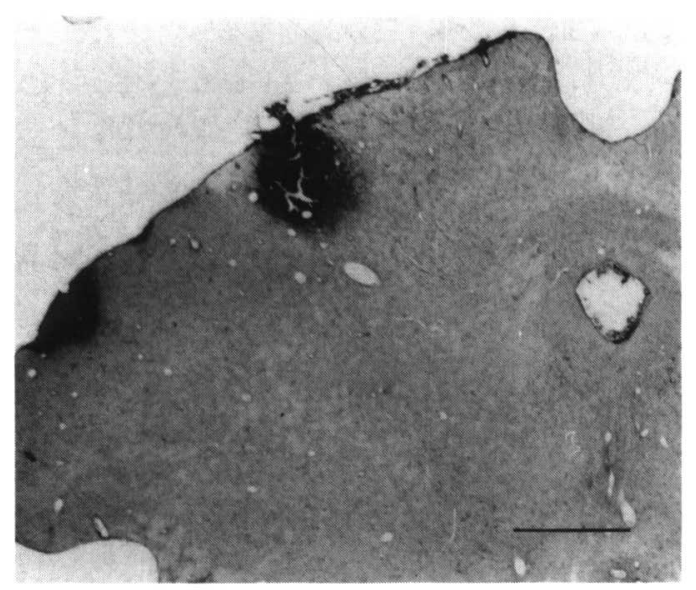

図 1 WGA-HRP の注入部位（C48）

WGA-HRP はNOT に限局し， 拡散は僅かである。

右下のバーは $1 \mathrm{~mm}$ を示す。

の注入部位を図 1 に, 脳組織標本のトーレスを図 2 に示す。C48 および C53 の注入部位は NOT に 限局し, WGA-HRP の拡散は視蓋前域視下核 (N $\mathrm{PSO})$, 後視蓋前域核 (NPP) に僅かながら及ん でいた。

\section{$<$ WGA-HRP 標識細胞>}

C48 およびC53 ともにNOT 注入側と同側では optic disc を含んだ水平線より上方でかつ optic disc を含んだ垂線より側頭側の網膜上に WGAHRP 標識細胞が認められ, 特に中心野 (Ares centralis）とその周囲に標識細胞が高密度で存在し た。一方, 対側では同側と同様に, optic disc を 含んだ水平線より上方でかつ optic disc を含ん だ垂線より側頭側の網膜上にのみ認められ, 特に 中心野とその周囲に標識細胞が高密度で存在した。 図 3 にC48 の眼杯伸展標本を示す。

標識細胞は, Boycott \& Wässle (1974) ${ }^{11)}$ の報 告のような網膜神経節細胞で, 概ね, 樹状突起の 発達している大細胞すなわち $\alpha$ 細胞 (直径約 30 $\mu \mathrm{m}$ ), 中細胞すなわち $\beta$ 細胞 (直径約 $20 \mu \mathrm{m}$ ), 樹状突起はある程度発達しているが小型の細胞す なわち, $\gamma$ 細胞 (直径 $5 \mu \mathrm{m}$ ) の三型に分類された (図 4)。

〈標識された網膜神経節細胞の密度〉

WGA-HRP の拡散が NOT に最む限局してい た C48 の注入側と同側の眼杯伸展標本と細胞密 度を図 5 に示し, 各部位の細胞構成を細胞体の面

\section{C48 \\ ROSTRAL}

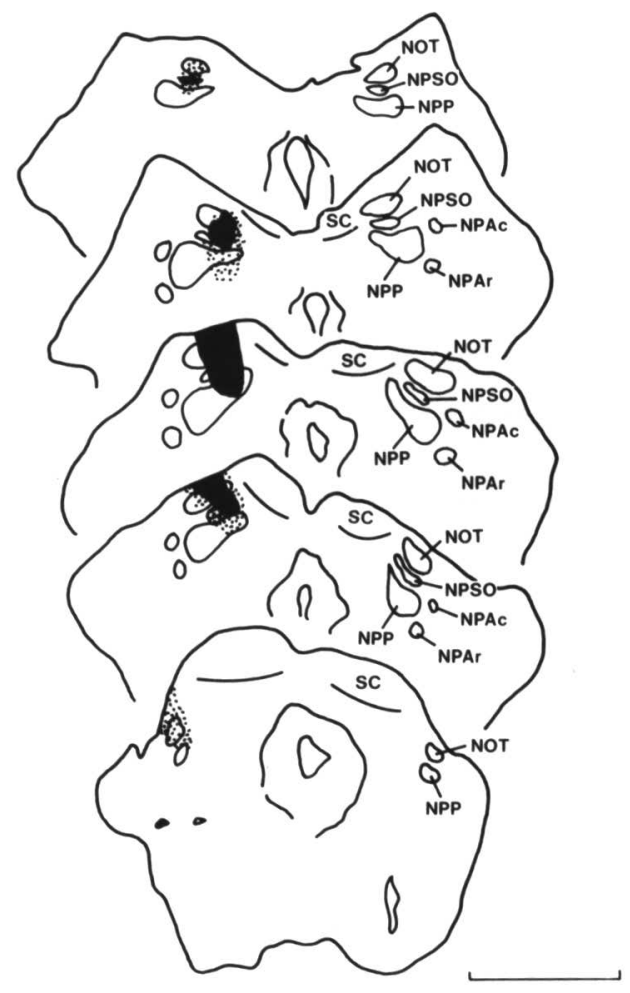

CAUDAL

図2 左 NOT 注入例の脳組織標本のトレー ス (C48)

WGA-HRP の拡散は NOT が中心で, 僅かに NPSO, NPP に及んでいる。 組織標本の間隔は $500 \mu \mathrm{m}$ で, 右下の バーは $5 \mathrm{~mm}$ を示す。

NOT : 視索核

NPAc：前視蓋前域核緻密部

NPAr：前視蓋前域核網様部

NPSO : 視蓋前域視下核

PPN : 後視蓋前域核

$\mathrm{SC}$ : 上丘

積で検討したヒストグラムを図 5 に示す。細胞密 度では中心野領域部 (C) が最大で, 次いで背側部 (D), 側頭部 (T) の順に疎となるが, 密度につい ては, 背側部 (D), 側頭部 (T) では差がなく, 鼻 側部の細胞密度は極めて低かった。次に細胞構成 をみると, 背側部 (D) を除いて各部位とも $100 \mu$ $\mathrm{m}^{2}$ 未満にピークを認め, 大部分が $200 \mu \mathrm{m}^{2}$ 未満 の細胞であった。一方, 対側あ同様に図 6 のごと 


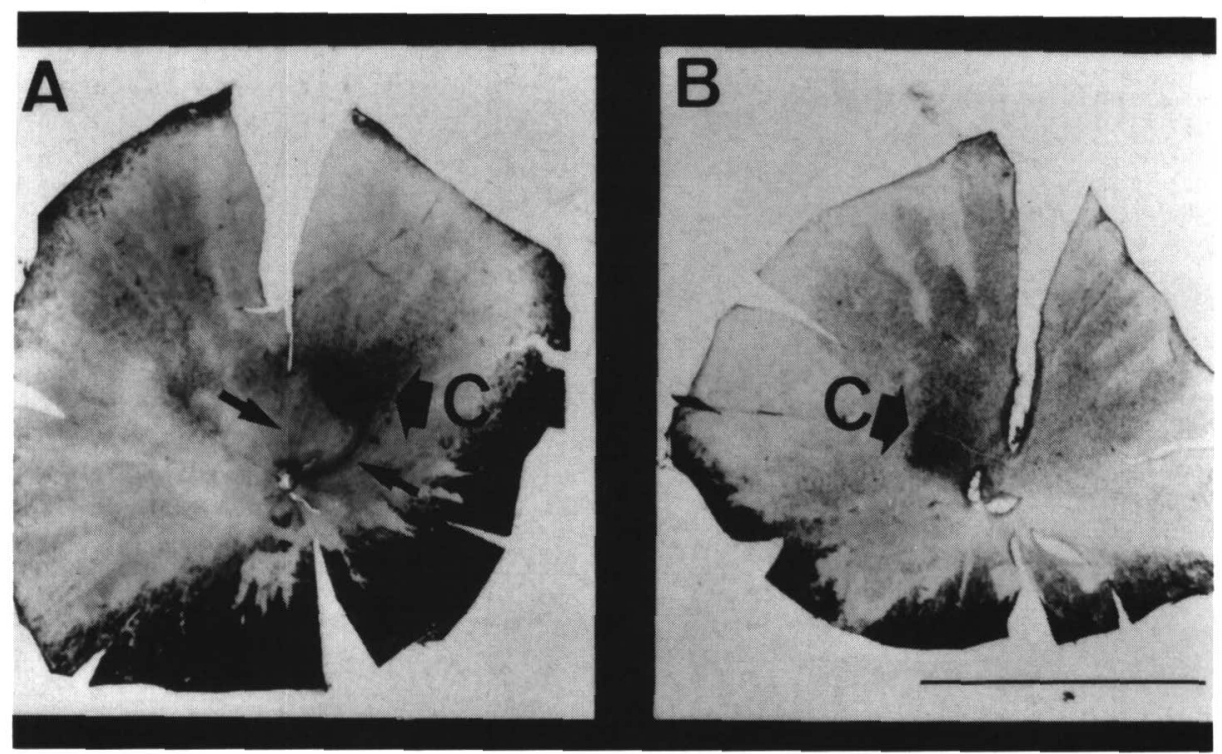

図 3 C 48 の眼杯伸展標本

$\mathrm{A}$ ：注入側と同側網膜 (左眼)

$\mathrm{B}$ ：対側網膜（右眼）

図中の C は中心領域部, 矢印は optic disc から延びた

fiber を示し, 右下のバーは $10 \mathrm{~mm}$ を示す。

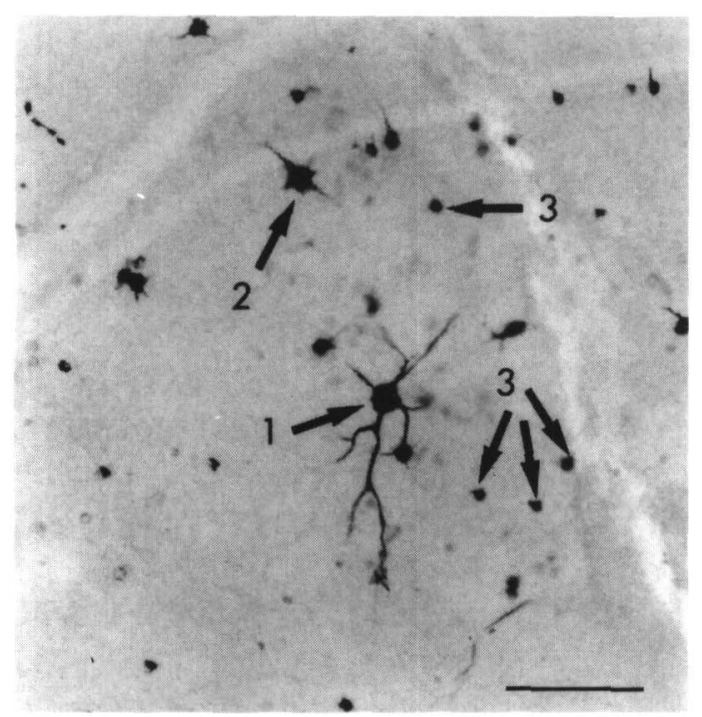

図 4 標識された網膜神経節細胞

矢印 1 は $\alpha$ 細胞（直径約 $30 \mu \mathrm{m}$ ), 矢印 2 は $\beta$ 細胞 (直径約 $20 \mu \mathrm{m}$ ), 矢印 3 は $\gamma$ 細 胞（直径約 $5 \mu \mathrm{m}$ )。 右下のパーは $100 \mu \mathrm{m}$ を示す。
く細胞密度では中心野領域部 (C) が最大で, 次い で背側部 (D 1, D 2), 側頭部 (T) の順に疎となり, 背側部 (D 1, D 2), 側頭部 (T) は共に低密度で, 鼻側部の細胞密度は極めて低かった。細胞構成も 同様 (図6) で, 背側部 (D 1, D 2) を除いて各部 位とも $200 \mu \mathrm{m}^{2}$ 未満にピークを認め, 大部分が $200 \mu \mathrm{m}^{2}$ 末満の細胞であった C 53 の細胞密度お よび各部位の細胞構成も C48 の結果と同様であっ た。

また, 中心野領域部 (C) 細胞密度の同側之対側 との比は, C48で 1: 1.4, 他の一匹の WGA-HR P が NOT にほぼ限局していた C53では $1: 1.7$ と対側の細胞密度が優位であった。その他の部位 では細胞密度の同側と対側との比に一定傾向を見 出せなかった。

\section{考 察}

OKN の解発には大脳皮質を経由するルートと 皮質下のルートが関与している(16) 17)。ネコ，サル におけるNOT の破壊実験で, 破壊側に向かう視 運動刺激に対して OKN が全く解発されず，皮質 経由の OKN に関する情報む脳幹に入る時は NO T を経由するであろうことがわかった ${ }^{918)}$ 。した 

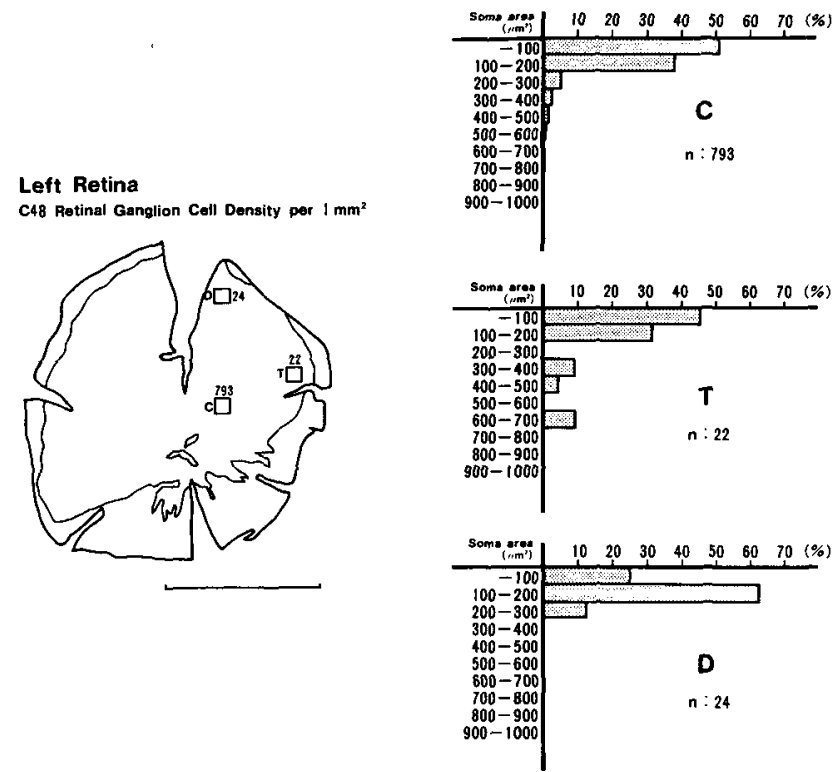

図 5 C48 の同側網膜の眼杯伸展標本のシェーマおよび各部位の細胞構成 細胞密度では中心野領域部 (C) が最も高く, 背側部 (D), 側頭部 (T) の順で疎となるが, 低密度で D と Tでは差がなかった。 細胞構成では, D を除いて $100 \mu \mathrm{m}^{2}$ 末満の細胞にピークを認め，大部 分の細胞が $200 \mu \mathrm{m}^{2}$ 末満であった。 シェーマ内の数字は各部位の $1 \mathrm{~mm}^{2}$ あたりの細胞密度を示し，シェー マ右下のバーは $10 \mathrm{~mm}$ を示す。

がって，逆行性軸索多動物質を NOT に注入し， 逆行性に標識される網膜神経節細胞を検討すれば, OKN の視覚情報の入力レベルと OKN の第一中 継核 NOT との結びつきが明確になるはずである。 1. WGA-HRP の拡散について

Mesulam $^{12)}$ によれば，濃染された領域が注入部 位として限定され，淡染領域は拡散であるとされ， TMB 法で観察された順行性および逆行性標識の 分布は注入部位の大きさの増大を反映しない可能 性を示唆している。NPP は対光反射に関与して いる可能性が最近の実験で示唆されており ${ }^{19121)}$, OKN との直接的な関係はないが，一部 HRP が 拡散している可能性は否定できない。なお，NPS $\mathrm{O}$ の機能的背景は不明である。

2.WGA-HRPにより標識された網膜神経節細 胞について

Stone $(1983)^{22)}$ によれば，ネコにおいて，受容 野の性質および軸索のインパルス伝導速度の相違 により網膜神経節細胞は機能的に Y 細胞, X 細胞, $W$ 細胞の三型に分類されている。この三型分類
は, Boycott \& Wässle (1974) ${ }^{15)}$ が網膜神経節細 胞を形態学的に $\alpha$ 細胞, $\beta$ 細胞, $\gamma$ 細胞の三型に 分類した手のとそれぞれ合致をみている22)。今回 の実験で大細胞と中細胞, 中細胞と小細胞との境 を明確にすることは，一次元的な直径では困難で あったので，より一層立体に近い二次元である面 積を用いて，標識された網膜神経節細胞の検討を 行ったが, 図 5,6にみる如く, 細胞構成のピーク は $100 \mu \mathrm{m}^{2}$ 末満のもの, 100-200 $\mu \mathrm{m}^{2}$ の群, さら に $200 \mu \mathrm{m}^{2}$ 以上の群之大別すれば，網膜神経節細 胞の直径および形態を観察した Stone $(1983)^{22)}$ と Boycott \& Wässle (1974) ${ }^{15)}$ ら報告を総合する 之, 樹状突起は発達しているが小型のW 細胞（直 径約 $5 \mu \mathrm{m}$ ), 中型の $\mathrm{X}$ 細胞 (直径約 $15 \mu \mathrm{m}$ 前後), 非常に樹状突起が発達しており大型の Y 細胞（值 径約 $30 \mu \mathrm{m}$ ）の三グループと見做すこともできよ う。

細胞密度に関して, Stone $(1965)^{233}$ は density map を作成し, 中心野の中心部では 6000 個 $/ \mathrm{mm}^{2}$, 中心野の周辺部では $1000-2000$ 個 $/ \mathrm{mm}^{2}$ で背側部 
Right Retina

C48 Retinal Ganglion Cell Density per $1 \mathrm{~mm}^{2}$
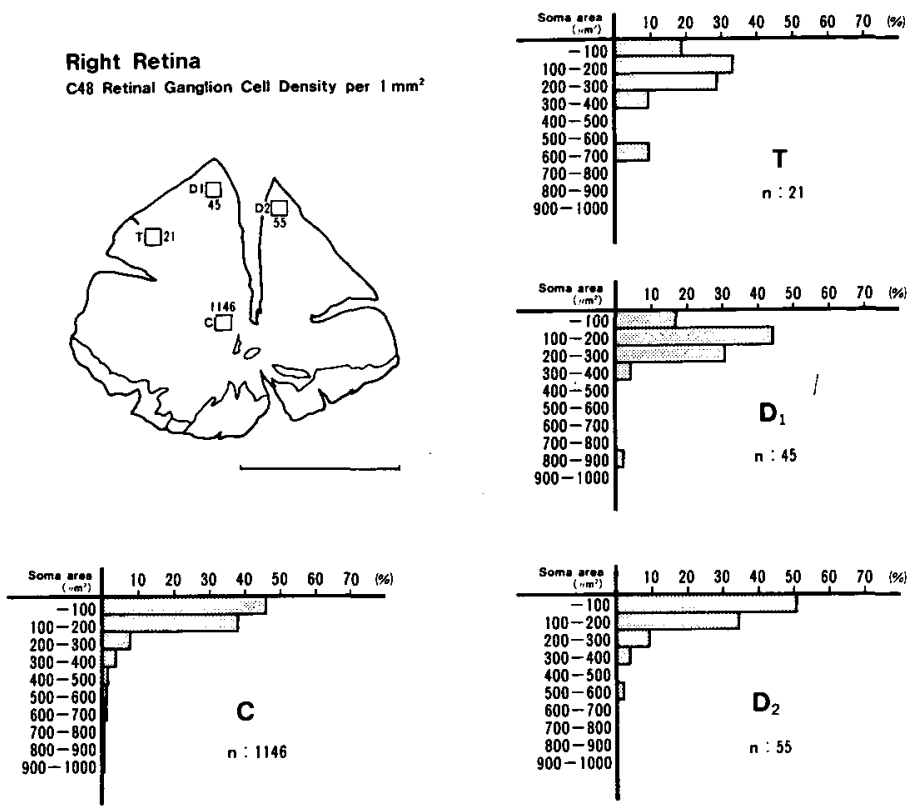

図 $6 \mathrm{C} 48$ の対側網膜の眼杯伸展標本のシェーマおよび各部位の細胞構成 細胞密度では中心野領域部 (C) が最 す高く，背側部 (D1，D 2)，側 頭部 (T) の順で蹯となるが, D1, D2 と T は共に低密度であった。 細胞構成では, D 1, D 2 を除いて $200 \mu \mathrm{m}^{2}$ 末満の細胞にピークを認 め, 大部分が $200 \mu \mathrm{m}^{2}$ 未満であった。シェーマ内の数字は各部位の

一 $1 \mathrm{~mm}^{2}$ あたりの細胞密度を示し, シェーマ右下のバーは $10 \mathrm{~mm}$ を 示す。 $\mathrm{n}$ 注単位面積あたりの全綱膜神経節細胞数を示す。

表 1 C 48, C53 の同側・対側網膜の各部位のX細 胞様細胞, Y 細胞様細胞および W 細胞様細胞 の割合

同側・対側繶膜共に中心野領域部で W 細胞様 細胞, X細胞様細胞およびY 細胞様細胞の 3 種が分布し，中でもW 細胞様細胞の比率が高 かった。その他の部位については一定傾向は 認められなかったが, 対側の背側部について は，Y細胞様細胞の比率が高い傾向にあった。 Ips : 同側網膜, Ctr : 対側網膜, Central : 中心野領域部, Temporal：側頭部, Dorsal, Dorsal 1, Dorsal 2: 背側部 表中の数字は各部位の单位面積あたりの全網 膜神経節細胞数に対する百分率を示す。

\begin{tabular}{|c|c|c|c|c|c|c|c|}
\hline & \multirow{2}{*}{$\begin{array}{l}\text { Cell class } \\
\text { Soma area }\end{array}$} & \multirow{2}{*}{\multicolumn{2}{|c|}{$\frac{W \text { - like cell }}{<100}$}} & \multirow{2}{*}{\multicolumn{2}{|c|}{$\frac{X \text {-like cell }}{100-200}$}} & \multirow{2}{*}{\multicolumn{2}{|c|}{$\frac{Y \text { - like cell }}{200<{ }_{(\mu \mathrm{m}}}$}} \\
\hline & & & & & & & \\
\hline & & $\mathrm{C} 48$ & $\mathrm{C53}$ & $\mathrm{C} 48$ & $\mathrm{C} 53$ & $\mathrm{C} 48$ & $\mathrm{C} 53$ \\
\hline \multirow[t]{3}{*}{ Ips } & Central & 50.8 & 63.0 & 38.7 & 25.5 & 10.5 & 10.5 \\
\hline & Temporal & 45.5 & 57.6 & 31.8 & 30.3 & 22.7 & 12.1 \\
\hline & Dorsal & 25.0 & 32.8 & 62.5 & 14.8 & 12.5 & 52.4 \\
\hline \multirow[t]{4}{*}{$\mathrm{Ctr}$} & Central & 46.0 & 34.8 & 38.3 & 36.0 & 15.7 & 29.2 \\
\hline & Temporal & 19.0 & 35.0 & 33.3 & 52.5 & 47.7 & 12.5 \\
\hline & Dorsal 1 & 17.8 & 33.9 & 44.4 & 21.0 & 37.8 & 45.1 \\
\hline & Dorsal 2 & 50.9 & 19.1 & 34.5 & 15.7 & 14.6 & 65.2 \\
\hline
\end{tabular}

では 125 個 $/ \mathrm{mm}^{2}$ 以下であったと述べている。今 回の実験結果からは各部位の数値は共に上記以下 でありここれら標識された網膜神経節細胞の機能 関連が示唆された。

\section{OKN と網膜神経節細胞について}

標識された網膜神経節細胞の大きさが $100 \mu \mathrm{m}^{2}$ 末満のものを $\mathrm{W}$ 細胞様細胞, $100-200 \mu \mathrm{m}^{2}$ の群を $\mathrm{X}$ 細胞様細胞, さらに $200 \mu \mathrm{m}^{2}$ 以上の群を $\mathrm{Y}$ 細胞 様細胞と仮定すると，本実験結果では同側および 対側ともに中心野領域部 (C) で W 細胞様細胞, $\mathrm{X}$ 細胞様細胞および $\mathrm{Y}$ 細胞様細胞の 3 種が分布し， 中であ W 細胞様細胞の比率が高かった。その他 の部位については一定傾向は認められなかったが, 対側の背側部 (D)についてはY 細胞様細胞の比 率が高かった（図 5，6，7，表 1）。

ネコにおいて, 福田 $(1975)^{24)}$ はX 細胞と W 細 胞はともに，中心野集中型の分布を示すのに対し， $\mathrm{Y}$ 細胞は比較的平坦な分布をなしていると述べ, したがって，本実験結果も福田 (1975) ${ }^{24)}$ の報告 を支持するすのと考えられた。一方，功て HR 
P NOT に注入している Ballas（1981）ら"は 逆行性に標識される網膜神経節細胞を数が少ない ながらも検討し， $\alpha, \gamma$ 細胞を見出しているが，両 側眼共に optic disc を含んだ水平線上部に，こ れらの網膜神経節細胞は存在し, 同側では中心野 付近の側頭側に13個の細胞のみで結果の考察を避 け, 刘側の標識細胞119個について論じている。 中心野はほとんどが $100 \mu \mathrm{m}^{2}$ 未満の $\gamma$ 細胞で構 成され， $\alpha, \beta$ 細胞はまったく存在せず，周辺部で あ $100 \mu \mathrm{m}^{2}$ 未満の $\gamma$ 細胞がほとんよ゙で, $200 \mu \mathrm{m}^{2}$ 以上の $\alpha$ 細胞は 6 個存在し, $\beta$ 細胞はまったく存 在しなかったとしている。本実験結果は100-200 $\mu \mathrm{m}^{2}$ のX細胞様細胞も少なからず存在し, Ballas (1981）ら ら) の結論と異にするむのであるが, 標識 された網膜神経節細胞の部位などはほぼ一致をみ

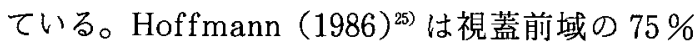
の細胞が W 細胞の発火に応じ，そのほとんどが NOT に入力しているといい, W 細胞が OKN に 関係があるにせよ $W$ 細胞以外の細胞の関与む容 易に想定され ${ }^{1)}$, 本実験結果からむ $\mathrm{X}$ 細胞, $\mathrm{Y}$ 細胞のある程度の関与が考えられた。また，本実 験結果から同側と対側ともに中心野領域 (C) に 最も細胞密度が高かったことを考え合わせると中 心野領域部 (C) が OKN の視覚情報の入力レベ ルでの果たす役割の重要性が示唆された。

4. binocular overlap の役割について

中心野領域部 (C) 細胞密度は同側之対㑡共に 最も高く, 同側と対側との細胞密度の比は, C48 で $1: 1.4$, C 53 では $1: 1.7$ と対側の細胞密度が優 位であった。したがって，中心野の存在する部位 および OKN に応ずる網膜神経節細胞の存在する 部位が OKN の方向性を支配する可能性が考えら れる。事実, Montarolo ら (1981) 18) はネコの交 叉性線維は視運動性刺激が側頭一鼻方向の時に, 非交叉性線維は視運動性刺激が鼻一側頭万向の時, 解発されやすいと述べている。本実験結果から同 側, 対側共に optic disc を含んだ水平線より上方 で，しかも中心野を含んだ側頭側の網膜上にのみ， WGA-HRP 標識細胞が認められ, 特に中心野と その周囲に標識細胞が高密度で存在することが判 明した。ネコの中心野の位置, 本実験において標 識された網膜神経節細胞の分布から，その視野は 鼻前下部の binocular overlap があり, Montarolo ら $(1981)^{18)}$ の生理実験結果を支持するもので
ある。

\section{まとめ}

視蓋前域にある NOT は哺乳類において, 中心 窝の有無にかかわらず, 網膜より入る OKN の視 覚情報の第一中継核とみなされている。しかしな がら, 網膜のどの部位の, よ゙のような網膜神経節 細胞が NOT に線維連絡を行っているかは論議む みられ，未解明の点も多い。

今回私共は，逆行性軸索移動物質であるWGAHRP ネコ NOTに注入し，逆行性に標識され る網膜神経節細胞を検討したところ，注入部位と 同側, 対側共に optic disc を含んだ水平線より上 部でかつ optic disc を含んだ垂線より側頭側の 網膜上に分布していた。最も細胞密度の高い部位 は中心野とその周囲であった。大多数の標識され た網膜神経節細胞は，小細胞の範疇で，いわゆる $\mathrm{W}$ 細胞で占められていたが， $\mathrm{X}$ 細胞様細胞， $\mathrm{Y}$ 細 胞様細胞む明らかに標識されており，これらの細 胞も視覚情報の入力レベルで OKN の解発に加わ っている可能性が示唆された。

\section{文献}

1) 岡田智幸 : 視索核に投射する網膜神経節細胞 の分布について一視運動性眼振と関連して 一. 日耳鼻 $92: 1947-1957,1989$

2) Okada T, Kato I, Sato S, et al : Retinal ganglion cells projecting into the nucleus of the optic tract in the rat. Acta Otolaryngol Suppl (Stockh) $481: 227-229,1991$

3 ) Kato I, Okada T, Watanabe S, et al : Retinal ganglion cells related to optokinetic nystagnus in the rat. Acta Otolaryngol (Stockh) $112: 421-428,1992$

4) Ballas I, Hoffmann K-P, Wagner H-J : Retinal projection to the nucleus of the optic tract in the cat as revealed retrograde transport of horseradish peroxidase. Neurosci Lett $26: 197-202,1981$

5) Sawai H, Fukuda Y, Wakakuwa K : Axonal projections $\mathrm{X}$-cells to the superior colliculua and to the nucleus of the optic tract in cats. Brain Res $341: 1-6,1985$

6) Cazin L, Precht W, Lannou J : Pathways mediating optokinetic responses of vestibular nucleus neurons in the rat. Pflugers 
Arch $384: 19-29,1980$

7) Collewijin $\mathrm{H}$ : Oculomotor areas in the rabbits midbrain and pretectum. J Neurobiol $6: 3-22,1975$

8 ) Precht $W$, Strata $P:$ On the pathway mediating optokinetic responses in vestibular nuclear neurons. Neurosci 5 : 777-787, 1980

9) Kato I, Harada K, Hasegawa $T$, et al : Role of the nucleus of the optic tract of monkeys in optokinetic nystagmus and optokinetic after-nystagmus. Brain Res 474:16-26, 1988

10) Mustari $M J$, Fuchs AF : Discharge patterns of neurons in the pretectal nucleus of the optic tract (NOT) in the behaving primate. J Neurophysiol $64: 77-90,1990$

11) Olucha F, Marrtinez-Garcia, Lopez-Garcia : A new stabilizing agent for tetramethyl benzidine (TMB) reaction reaction product in the histochemical detection of horseradish peroxidase (HRP). J Neurosci Meth $13: 131-138,1985$

12) Mesulam MM : Tetramethyl benzidine for horseradish peroxidase neurohistochemistry: A non-carcinogenic blue reactionproduct with superior sensitivity for visualizing neural afferents and efferents. $J$ Histochem Cytochem $26: 106-117,1978$

13) Mesulam MM, Hegaty E, Barbas H, et al : Additional factors influencing sensitivity tetramethyl benzidine method for horseradish peroxidase neurohistochemistry. J Histochem Cytochem $28: 1255-1259$, 1980

14) Kanaseki T, Sprague JM : Anatomical organization of pretectal nuclei and tectal laminae in the cat. J Comp neurol 158 : 319-338, 1974

15) Boycott BB, Wässle $H$ : The morphological types of ganglion cells of the domestic cats reting. J Physiol 240:397-419,
1974

16) Precht $W:$ Visual - vestibular interaction in vestibular neurons: Functional pathway organization. Ann NY Acad Sci 374 : 230-248, 1981

17) Ter Braak JWG : Untersuchungen ueber optokinetischen nystagumus. Arch Neerl Physiol $21: 309-376,1936$

18) Montarolo PW, Precht W, Strata P : Functional organization of the mechanisms subserving the optokinetic nystagmus in the cat. Neuroscience $6: 231-246,1981$

19) Clarke RJ, Ikeda $\mathrm{H}$ : Luminance and darkness in the olivary and posterior nuclei and their relationship to the pupillary light reflex in the rat. I Studies steady luminance levels. Exp Brain Res 57 : 224232, 1985

20) Clarke RJ, Ikeda $\mathrm{H}$ : Luminance datectors in the olivary pretectal nucleus and their relationship to the puillary light reflex in the rat. II. Studies using sinusoidal light. Exp Brain Res $59: 83-90,1985$

21）関谷治久: 対光反応の中枢機構. 神経進歩 $29: 744-751,1985$

22) Stone $J:$ Parallel processing in the visual system. Plenum Press, New York and London, 1983

23) Stone J:A quantitative analysis of the distribution of ganglion cells in the cats retina. J comp neurol $124: 337-352,1965$

24）福田 淳: 視覚中枢入力の多元性 一ネコ網 膜神経節細胞の三型分類一. 生体の科学 26 : 442-452, 1975

25) Hoffmann KP : Visual inputs relevant for the optokinetic nystagmus in mammals. Prog Brain Res 64:75-84, 1986

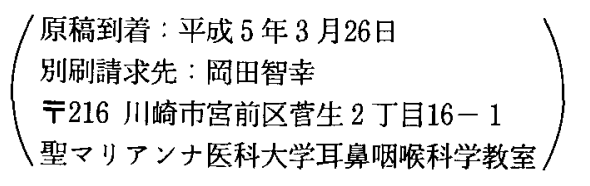

